IJOEM

18,1

86

Received 5 May 2020

Revised 4 November 2020 22 February 2021

20 March 2021

Accepted 23 March 2021

\section{Subsidiary banks in emerging markets: how strong is the coordination on a group-wide basis?}

\author{
Małgorzata Iwanicz-Drozdowska \\ Institute of Finance, Szkoła Gtówna Handlowa w Warszawie, Warszawa, Poland, and \\ Bartosz Witkowski \\ Institute of Econometrics, Szkoła Gtówna Handlowa w Warszawie, Warszawa, \\ Poland
}

\begin{abstract}
Purpose - The parent-subsidiary nexus has been explored since the mid-1990s, but the extent to which subsidiaries resemble their parents remains unclear. Therefore, this study examines the performance drivers for subsidiary banks in emerging markets and their parents to determine the similarities between these groups. The findings could help identify key financial performance measures that should be included in global strategies for multinational banks operating in emerging markets.

Design/methodology/approach - The study uses data on subsidiaries from 32 countries, including 20 European transitioning countries and 49 parent companies operating internationally from 1996 to 2015. It considers several models that distinguish between units using individual bank effects and the stochastic structure. In a robustness analysis, EU- and non-EU-based institutions are distinguished and long-term historical links between parents' and subsidiaries' countries are considered.

Findings - Cost control, capital adequacy and asset quality policies have similar importance for parent banks and subsidiaries and are strictly coordinated, whereas the remaining policies allow more flexibility. Subsidiaries in the EU and in countries that were politically and/or militarily influenced by parent countries do not "fall far from the tree", which signals their strong group-wide integration and coordination.

Research limitations/implications - This study covers a limited number of emerging market countries due to the limited availability of long-term series data. Future studies should include more countries.

Originality/value - This study identifies key financial measures used on a group-wide basis for performance management while accounting for long-term relations between host and home countries and the geopolitical characteristics of host countries.
\end{abstract}

Keywords Performance, Foreign-owned banks, Emerging markets

Paper type Research paper

\section{Introduction}

Scholars have analyzed the "parent-subsidiary nexus" phenomenon since the mid-1990s. Houston et al. (1997) and Houston and James (1998) noted that an "internal capital market" operates between the parent company and its subsidiaries. Peek and Rosengren $(1997,2000)$ noted the existence of shocks transmitted from parent companies to their subsidiaries. However, foreign bank subsidiaries are influenced not only by parent policies but also, to some

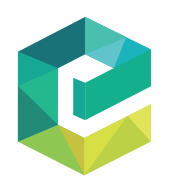

(C) Małgorzata Iwanicz-Drozdowska and Bartosz Witkowski. Published by Emerald Publishing Limited. This article is published under the Creative Commons Attribution (CC BY 4.0) licence. Anyone may reproduce, distribute, translate and create derivative works of this article (for both commercial and noncommercial purposes), subject to full attribution to the original publication and authors. The full terms of this licence may be seen at http://creativecommons.org/licences/by/4.0/legalcode

The authors would like to thank the Editor and the anonymous Reviewers for their insightful comments and suggestions. This paper is based on research conducted in 2018-2019 in the Management and Finance Collegium at Warsaw School of Economics (Poland). Grant number: KZIF/S/19/18.
International Journal of Emerging Markets

pp. 86-101

Emerald Publishing Limited

1746-8809

DOI 10.1108/IJOEM-05-2020-0487
Vol. 18 No. 1, 2023 
extent, by idiosyncrasy. Therefore, an interesting research question arises: to what extent do subsidiaries resemble their parents? These similarities can be analyzed through different lenses, e.g. performance or business models. Because this paper analyses subsidiaries operating in emerging markets (20 European transitioning countries, excluding Russia, 8 Latin American countries and 4 Asian countries), the focus on performance should provide interesting results because significant differences may be observed between home countries (i.e. countries of foreign investors) and host countries (i.e. countries in which subsidiaries operate), especially in terms of economic and financial development. This investigation is motivated by observations of the "push effect" (e.g. Jeanneau and Micu, 2002), which encourages banks to expand abroad to attractive regions. As noted by Lo and Tan (2019), the performance of subsidiaries plays an important role in multinational enterprises' global strategy. Therefore, an in-depth analysis of the performance drivers of foreign-owned banks in emerging markets that accounts for the heterogeneity of countries would help in the development of global strategies for parent banks.

Studies have compared the profitability of foreign-owned and domestic-owned banks (e.g. Dahl et al. (2008) adopted a convergence perspective, and Chen and Liao (2011) focused on joint home and host country effects) as well as that of foreign-owned banks in developed and emerging markets (e.g. Claessens et al., 2001), revealing that subsidiaries in developed countries were less profitable than those in emerging markets. Some studies have explored the profitability of foreign-owned banks in emerging markets from the perspective of their market entrance strategy (e.g. Havrylczuk and Jurzyk, 2011b) or takeover strategy (Havrylczuk and Jurzyk, 2011a). A cross-country study by Dietrich and Wanzenried (2014) presented the determinants of profitability in low-, middle- and high-income countries, concluding that determinants vary among countries with different income levels. There are also single-country studies that focus on the impact of the parent company on the performance of subsidiaries (e.g. Kosmidou et al., 2007 for Greece) or the factors determining foreign-owned banks' performance (e.g. To and Tripe, 2002 for New Zealand and Sturm and Williams, 2008 for Australia).

The present study focuses on emerging markets with the intention of expanding the stream of research presented by Chen and Liao (2011) and Dietrich and Wanzenried (2014). Lo and Tan (2019) indicated that the literature investigates parent companies and their subsidiaries separately. Moreover, there is a lack of a comprehensive method to measure differences or to diagnose how traits of both entities (i.e. parents and subsidiaries) affect subsidiary performance. This study aims to fill in this gap, at least to some extent. The goal is to analyze the similarity of the performance drivers of subsidiaries and their parent companies while accounting for long-term relations between the host and home countries and the geopolitical characteristics of the countries of subsidiaries. In comparison with previous studies, this study focuses on similarities between parent banks and subsidiaries instead of subsidiaries and their local competitors. Therefore, it expands the literature on foreign-owned banks in emerging markets and the determinants of their performance.

The paper is organized as follows. The second section presents a review of the relevant literature. The third section explains the data sources and methodology, while the fourth section presents and discusses the empirical results. The fifth and final section provides concluding remarks.

\section{Literature review}

The research on the determinants of banks' performance has focused either on large international (or regional) samples or single countries. The methodological approaches, including several sets of variables (i.e. internal, that is, bank-specific; idiosyncratic; and external, that is, industry and macroeconomic) and target groups of banks (foreign-owned banks only vs. all banks operating in a given country), vary across studies. The conclusions on determinants have not been unanimous and underline discrepancies among countries. Thus far, the similarities in performance drivers between subsidiaries and their parent 
IJOEM 18,1

companies have not been scrutinized in the literature. As Chen and Liao (2011) and Tan (2016) provided an in-depth review of previous studies on bank profitability, the review of the literature given here is complementary.

Different determinants of bank profitability have been identified in various studies. First, conclusions from single-country studies are discussed, followed by those from cross-country research. Athanasoglou et al. (2008) presented that for Greek banks with different ownership, profitability was shaped by bank-specific (e.g. bank capital and exposure to credit risk) and macroeconomic determinants (e.g. inflation), while industry-specific determinants and bank ownership were not important. Another single-country study based on Swiss banks (Dietrich and Wanzenried, 2011) showed that profitability was explained by operational efficiency (cost-to-income, or CI ratio), growth of total loans, costs of funding, business model and bank ownership (e.g. co-owned by the state or city or foreign-owned). Bank profits were also confirmed to be pro-cyclical. A single-country study on an emerging market country, China, was conducted by Tan (2016). In this case, banks' profitability was determined by the taxation rate (the ratio of taxes to operating profit before taxes), the ratio of overhead costs to total assets, labor force productivity (the ratio of gross revenue to the number of employees) and the inflation rate, while there was no robust evidence concerning the role played by risk and competition. In a single-country study, Ahamed (2017) presented a different perspective on the determinants of bank profitability for Indian banks for 1998-2014, drawing attention to income diversification and its importance for profits (ROA) and risk-adjusted profits (ROA divided by the SD of ROA). This study concluded that banks moving from interest income to non-interest income generated higher profits; however, the risk-adjusted profit was higher only for foreign-owned banks. Investigating profitability determinants (ROA) among banks in Sweden, Ohman and Yazdanfar (2018) indicated that organizational-level determinants play an important role in bank profitability and may be used by managers to define the basis for low-risk policy. They confirmed a positive role of capital adequacy, growth of revenues and lagged profitability. Other variables, e.g. size and GDP growth, were not important. Du et al. (2018) focused on the analysis of foreign-owned banks in Chile, which represents an emerging market with a strong institutional framework. It was found that foreign-owned banks played a positive role in providing credit to businesses and households. Moreover, subsidiaries of foreign banks increased competition in the market and thus decreased margins.

In a cross-country study of Latin American banks, Saona (2016) claimed that among bankspecific factors, asset diversification improves performance, while income diversification decreases it. Among external factors, the efficiency of the regulatory system and the reduction in abnormal profits played a negative role when the financial system improved. For the same region, Jara-Bertin et al. (2014) concluded that size, capital and business diversification as well as the rate of inflation increase profitability, while credit risk and administrative expenses decrease it. In a study by Beltratti and Paladino (2015), banks with high equity capital exhibited significantly higher levels of residual income in the short run, which underlines the role of bank capital in strategy. Although Le and Ngo (2020) analyzed different aspects of bank profitability, namely, the role of IT-based distribution channels, they found that lower concentration improves bank profitability, while higher capital and overhead cost reduce it. Moreover, they confirmed that in banking sectors operating in countries representing higher credit risk, banks charge higher interest to price the risk adequately.

In the extant literature, various determinants of bank profitability have been identified. Because foreign expansion requires a reasonable strategy, it should be expected that parent companies focus on certain financial performance measures to coordinate their profits on a group-wide basis. In practice, they need exact tools to control subsidiaries, and among them, certain financial ratios seem to be a reasonable solution due to their simplicity and transparency. Therefore, as the first hypothesis, it is suggested that (H1): on a group-wide basis, core financial measures are coordinated to achieve the target level of profitability. 
Similarities between parent banks and subsidiaries help identify these core financial measures since, as indicated in a review of the literature, different ratios for various country settings and periods revealed their importance for banks' performance.

As indicated by Chen and Liao (2011), cross-country differences impact foreign-owned banks' profitability, and under certain conditions (e.g. a less competitive banking sector, lower GDP growth rates and higher interest and inflation rates in the host country), allow higher profitability and stimulate regulatory arbitrage. Dietrich and Wanzenried (2014) conducted an analysis of the determinants of profitability for more than 10,000 banks from a large group of 118 countries from 1998 through 2012. The countries were divided into three groups based on income (low, middle and high). This analysis revealed that the level of income affects the significance of the determinants of bank profitability. Banks in high-income countries were found to be less profitable than those in lower-income economies, and disparities in competition were one of the main discriminating factors. In low-income countries, privately owned banks demonstrated more profitability than state-owned banks. Macroeconomic factors were proven to explain a large degree of the profitability of banks in low-income countries. The countries in the present study represent the low- and middle-income groups. Djalilov and Piesse (2016) concluded in their analysis of 16 early and late (mostly former Soviet Union) transitioning European countries that there are differences in performance determinants between early and late transitioning countries. Better capitalized banks are more profitable, and the impact of credit risk on early transitioning countries is positive. Moreover, Banyen and Biekpe (2020) provided evidence of a positive role of financial integration in bank profitability for a sample of 47 African countries, which represent another group of emerging markets. Importantly, banks in European transitioning countries are expected to benefit from financial integration with the EU. It is also worth noting that the Soviet Union had a strong influence on central, eastern and southeastern European countries until the early 1990s. Prior to that, other countries had strong influences on this region, e.g. Russia, Prussia (the predecessor to Germany), Austria and Turkey. Outside Europe, emerging markets in Latin America and Asia have been influenced by France, Spain, or Great Britain as former colonies. To date, this historical aspect has not been explored in the context of the parent-subsidiary nexus.

Against this background, we formulate two research hypotheses. As differences among different groups of countries exist, it is suggested that $(\mathrm{H} 2)$ for subsidiaries in more advanced emerging markets and their parents, profitability determinants are more similar than in the case of other subsidiaries, so "the apple does not fall far from the tree".

Because some home countries have had a strong impact on host countries in the past, it is suggested that $(\mathrm{H} 3)$ subsidiaries in host countries that have historical links with home countries of parent banks are under stricter control by their parents than subsidiaries in other countries. In this case, "the apple does not fall far from the tree".

\section{Data and methodology}

Following previous studies, this paper uses a set of macro- and microeconomic variables as potential regressors (Table 1). Three performance indicators are modeled: ROE, ROA and NIM (as in by Chen and Liao, 2011, Dietrich and Wanzenried, 2011, 2014 and Tan, 2016).

Bank-level data were collected from Bankscope and supplemented by hand-collected data on banks' owners (foreign-owned banks are those for which foreign owners account for at least $50 \%$ of shares), while the country-level data were extracted from the World Bank and IMF databases and central bank websites. Information about bank owners was obtained from banks' annual statements and websites. Thirty-two countries, including 20 European emerging markets (Albania, Belarus, Bosnia and Herzegovina, Bulgaria, Croatia, Czech Republic, Estonia, Hungary, Kosovo, Latvia, Lithuania, Macedonia, Moldova, Montenegro, Poland, Romania, Serbia, Slovakia, Slovenia and Ukraine) and 12 non-European countries (Argentina, Brazil, Chile, Colombia, India, Indonesia, Malaysia, Mexico, Panama, Peru, 
IJOEM 18,1

\begin{tabular}{|c|c|c|c|}
\hline Notation & Definition & Examples of use & $\begin{array}{l}\text { Expected } \\
\text { sign }\end{array}$ \\
\hline
\end{tabular}

Macroeconomic and market structure variables

GDP Change in GDP in real terms

INF Inflation rate (CPI)

CR5 Concentration ratio; the share of the

five biggest banks in the total assets of the banking sector in a country

Claessens et al. (2001), Havrylchyk + and Jurzyk (2011b), Claeys and Vander Vennet (2008), Beltratti and Paladino (2015), Albertazzi and Gambacorta (2009), Dietrich and Wanzenried (2011), Dietrich and Wanzenried (2014), Tan (2016), Saona (2016), Djalilov and Piesse (2016), Banyen and Biekpe (2020) Chen and Liao (2011), Claessens et al. (2001), Claeys and Vander Vennet (2008), Athanasoglou et al. (2008), Beltratti and Paladino (2015), Albertazzi and Gambacorta (2009), Dietrich and Wanzenried (2014), Jara-Bertin et al. (2014), Tan (2016), Saona (2016), Djalilov and Piesse (2016), Du et al. (2018), Banyen and Biekpe (2020)

CR3 - Claeys and Vander Vennet (2008), Dietrich and Wanzenried (2014), Jara-Bertin et al. (2014), Tan (2016), Saona (2016), CR4 - Chen and Liao (2011), CR5 - Kosmidou et al., (2007), Beltratti and Paladino (2015)

Bank-level variables

S_LOANS Loans to customers to total assets (TA)

$\begin{array}{ll}\text { D_L } & \begin{array}{l}\text { Deposits of customers to loans to } \\ \text { customers } \\ \text { EAP }\end{array}\end{array}$

CRED_GROWTH Credit growth $(n / n-1)$ in real terms CI Cost-to-income ratio

LIQ_A Liquid assets to deposits and shortterm funding
Madous and de Guevara (2004), Claeys and Vander Vennet (2008), Tan (2016), Saona (2016)

Similar to Chen and Liao (2011)

Claessens et al. (2001), Madous and de Guevara (2004), Athanasoglou et al. (2008), Claeys and Vander Vennet (2008), Havrylchyk and Jurzyk (2011b), Dietrich and Wanzenried (2011), Cull and Martínez Pería (2013), Jara-Bertin et al. (2014), Dietrich and

Wanzenried (2014), Tan (2016), Djalilov and Piesse (2016), Ahamed (2017), Ohman and Yazdanfar (2018), Banyen and Biekpe (2020)

Beltratti and Paladino (2015)

Dietrich and Wanzenried (2011, 2014), Tan (2016)

Similar to Chen and Liao (2011), Beltratti and Paladino (2015), Banyen and Biekpe (2020)

\section{Table 1.}




\begin{tabular}{|c|c|c|c|}
\hline Notation & Definition & Examples of use & $\begin{array}{l}\text { Expected } \\
\text { sign }\end{array}$ \\
\hline $\mathrm{COR}$ & $\begin{array}{l}\text { Cost of risk, defined as impairment } \\
\text { charges }{ }^{1} \text { to total assets, which } \\
\text { refers to asset quality }\end{array}$ & $\begin{array}{l}\text { The substitute for NPL due to a } \\
\text { limited number of observations; } \\
\text { credit risk proxy - Chen and Liao } \\
\text { (2011), LLP - Madous and de } \\
\text { Guevara (2004), Athanasoglou et al. } \\
\text { (2008), Havrylchyk and Jurzyk } \\
\text { (2011b), Jara-Bertin et al. (2014), } \\
\text { similar to Beltratti and Paladino } \\
\text { (2015), Dietrich and Wanzenried } \\
\text { (2011) }\end{array}$ & - \\
\hline SIZE & ln TA (ln of TA in million EUR) & $\begin{array}{l}\text { Athanasoglou et al. (2008), Chen } \\
\text { and Liao (2011), Mostak Ahamed } \\
\text { (2017), Dietrich and Wanzenried } \\
\text { (2014), Tan (2016), Djalilov and } \\
\text { Piesse (2016), Ohman and } \\
\text { Yazdanfar (2018), Du et al. (2018) }\end{array}$ & $+/-$ \\
\hline
\end{tabular}

Note(s): ${ }^{1}$ Impairment charges reflect, in profit and loss accounts, the cost of allowances (reserves) for non-performing loans and other impaired assets. These names are used under the framework of IAS 39

Table 1.

Philippines and Uruguay), were observed over the 1996-2015 period. This period of 20 years is long enough to analyze the role and performance of foreign-owned banks in emerging markets because it covers not only the years just after their entry, in which a given subsidiary is supposed to achieve a break-even point, but also at least a decade of "business as usual". This should allow us to identify banks' performance in a better-known environment and potentially under more stable conditions. The current study focuses on the international banking groups that are active within and outside of Europe managed by 49 parent companies (see Annex 1 for details). The selection of countries was based on the presence of foreign banks and its intensity, which, comparing regions, is the highest in transitioning Europe and Latin America. To a lower degree, these international banking groups are active in other markets, including Asia.

Given that historical links may play an important role in similarities between parent companies and subsidiaries, a dummy variable ("VASSAL") is introduced to indicate whether a given host country was politically and/or militarily influenced (conquered, vassalized or colonized) in the past by a given home country (see Annex 2 for details). For example, Central and Eastern European countries were under the strong political and military influence of the Soviet Union until the early 1990s. It is assumed that historical links are also important for doing business not only because of historical sentiment but also due to potential similarities in economic culture among countries. Moreover, to account for the heterogeneity of countries, host countries are divided into two subsamples: EU and non-EU, including Latin American and Asian countries.

The natural logarithm of the regressors is sometimes used in the case of variables whose distribution is highly asymmetric and exhibits high variance (most of the distribution is concentrated in the $<0 ; s>$ range, while $10 \%$ or more is concentrated in the $<s ; 100 s>$ range). In this case, the tail of the distribution might prevail over the body, and the coefficient will be determined solely for a minor subset of observations. The use of the logarithm flattens the distribution and eliminates this effect. This, however, might mean that the model will not reflect the assumed functional form of the relations between variables. Instead, we eliminate $1 \%$ of the outliers, taking into consideration only the variables with highly asymmetric distributions, as mentioned above. This results in a sample of 2,878 observations on banks operating in emerging countries (see Annex 1 for details). There are 849 bank-year 
IJOEM 18,1

\section{2}

observations for the parent companies of foreign-owned banks in the region, which decreases to 803 after eliminating outliers. However, the number of observations used to estimate particular models differs slightly because some of the regressors used in some of the models are missing in certain cases.

The bank-level data were used to estimate a series of panel regressions:

$$
y_{i t}=x_{i t}^{\prime} \beta+\alpha_{i}+\varepsilon_{i t},
$$

where $y_{i t}$, the dependent variable, is the bank's financial indicator (ROA, ROE or NIM) for the $i$-th bank in period $t ; x_{i t}^{\prime}$ is the vector of independent variables; $\beta$ is the vector of parameters; $\alpha_{i}$ is the bank-level individual fixed effect; and $\varepsilon_{i t}$ is the error term.

The natural rationale behind the choice of the fixed effects approach is that it requires the fewest assumptions (individual effects do not need to be uncorrelated with the regressors, as assumed in the random effects approach), but assumptions do exist in the model; thus, the risk of omitted variable bias does not exist in the case of time-invariant factors. In addition, to test the robustness of the results, the random effects estimator is used to estimate

$$
y_{i t}=x_{i t}^{\prime} \beta+\varepsilon_{i t},
$$

with feasible generalized least squares (GLS), which allows for first-order autocorrelation and cross-bank heteroscedasticity.

Three models are run, in which different performance indicators-ROA (Model 1), NIM (Model 2) and ROE (Model3) - are explained. The appropriate descriptive statistics (quartiles Q1-Q3) are provided in Annex 3. Except for the CI ratio and size, the values of quartiles are higher in the case of subsidiaries and their countries (host) than for parent banks and their countries (home). This finding confirms the existence of different market realities in host and home countries. In terms of CI, however, parents are more cost effective.

\section{Empirical results and discussion}

Section 4.1 presents and discusses the results of the estimation of the baseline models based on the full available sample, while Section 4.2 discusses the results for selected subsamples to account for cross-country heterogeneity (the tables are presented in Annex 4). In the discussion, whenever the concept of the significance of a variable is used, significance at the $10 \%$ level is assumed for brevity.

\subsection{Baseline model}

Tables 2-4 present the estimates of the models based on the entire available sample. Model 1.1 (with ROA as the dependent variable, 1.1.a for subsidiaries and 1.1.b for parent banks in Table 2) is treated as the benchmark baseline model and discussed in detail. Against this backdrop, this paper discusses the estimates of the models considering the other two dependent variables as well. While the individual effects are treated as fixed in the baseline model, in each case, the estimates of the one-way random effects model and the pooled model with non-spherical disturbances estimated with the use of GLS are provided.

The results of the estimation show that subsidiary and parent profitability coincides with a higher inflation rate, better bank capital adequacy and liquidity as well as a higher share of loans in bank assets. In contrast, the cost-to-income ratio and cost of risk deteriorate bank profitability. The role of these variables is robust across the analyzed models (except for the cost of risk in NIM model) and in line with expectations: the positive role of the inflation rate can be explained by high nominal interest rates, allowing higher profits through the channel of net interest income. One may notice that in an environment of low interest rates, such as the present one, banks generate lower profits due to lower margins. However, in emerging 


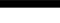


IJOEM
18,1

94
完

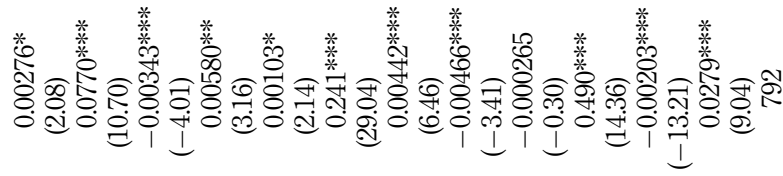

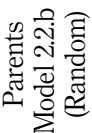

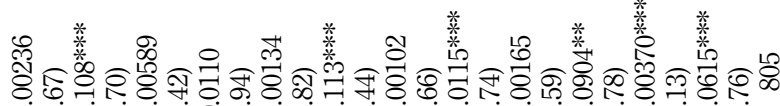

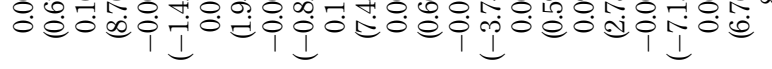

官

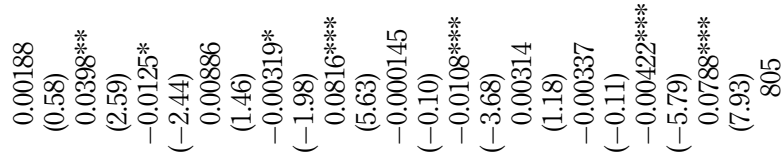

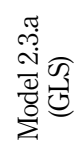

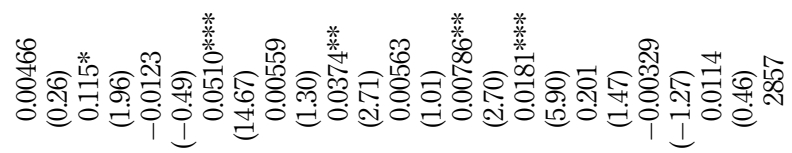

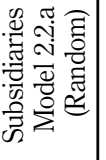
क

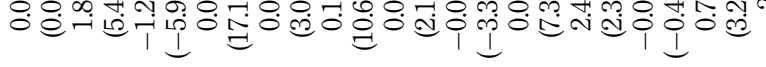

Table 3.

NIM models for all banks 


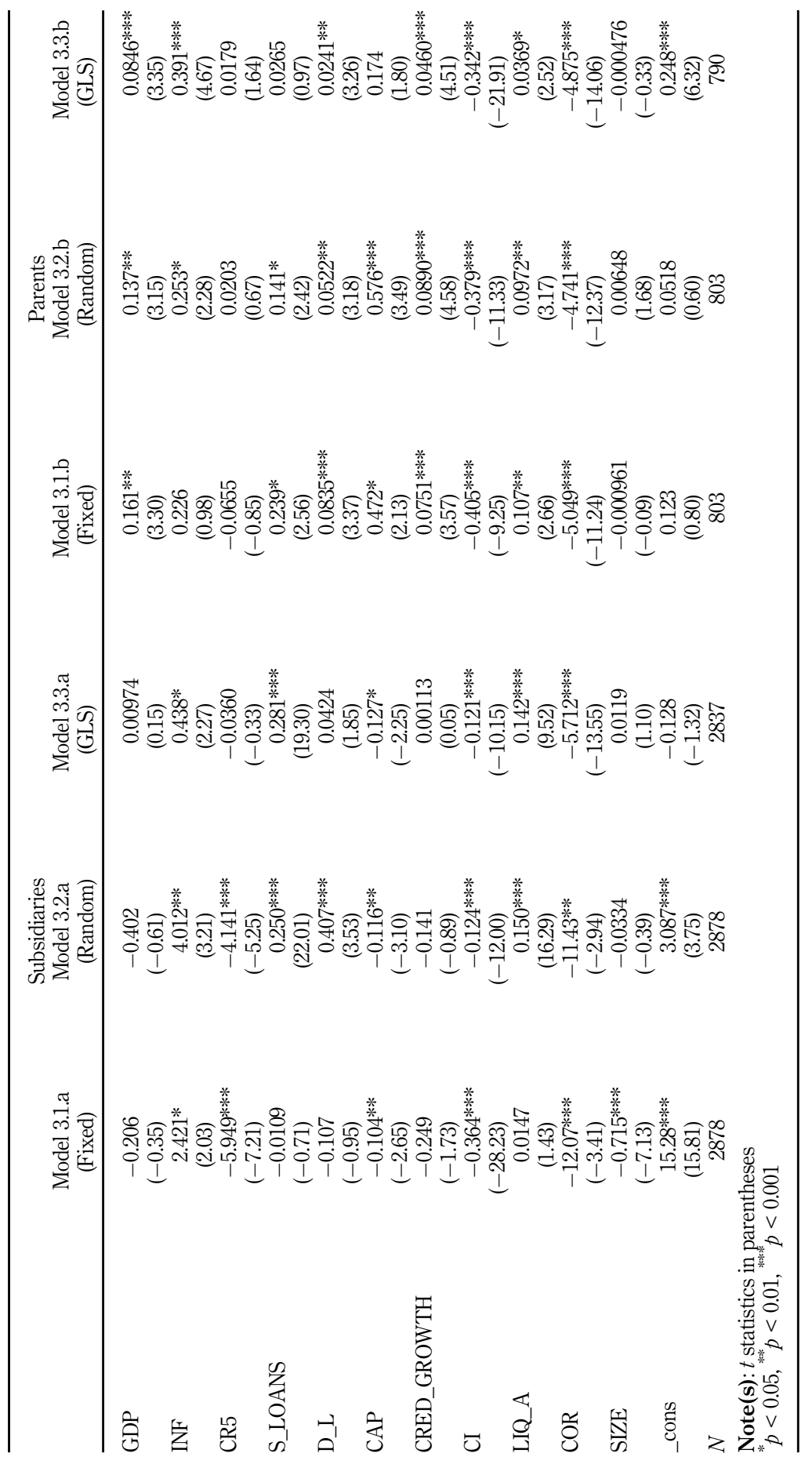

Subsidiary banks in emerging markets

95

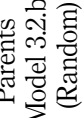

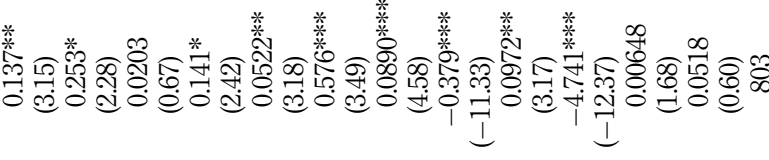


IJOEM 18,1

markets, credit risk increases margins. Therefore, a higher share of loans in bank assets allows for increased profitability, but its overall impact is reduced by the cost of risk that reflects the risk materialized in a given period. The impact of bank capital adequacy confirms the positive role of capital in profitability. Notably, good capital adequacy allows a decreased cost of funding because market participants trust more well-capitalized banks, but low leverage reduces the ability to increase the return on equity (ROE). Similar interlinkages can be observed with regard to the role of liquid assets and the structure of funding (called jointly liquidity). Satisfactory liquidity allows banks to avoid the emergency costs of funding, while at the same time, the excessive volume of liquid assets may decrease banks' profitability. However, subsidiaries have found a good balance and liquid assets do not deteriorate their profitability. The cost-to-income ratio confirms across all models its negative role in bank profitability, as expected. Only one exception (the NIM model for subsidiaries with GLS, 2.3.a), in which the sign of the coefficient is positive, is observed.

Considering the parent banks' situation (1.1.b), significance and signs consistent with the theory and model for subsidiaries were confirmed for the rate of inflation, capital adequacy, cost-to-income ratio, cost of risk and deposit-to-loan ratio, but the profitability determinants embrace a broader scope. GDP growth and credit growth coincide with better profitability of parent banks, while this is not the case for subsidiaries. This finding may suggest that parent banks are more influenced by the macroeconomic environment and credit policy than their subsidiaries because parent banks operate in larger-scale banking sectors (indicated by, e.g. the ratio of banking sector assets to GDP) in their home markets and therefore are more prone to economic downturns. The credit portfolio is usually less important for the parents' balance sheets (please refer to descriptive statistics in Annex 3), but its role in profitability is more stable than the roles of other activities, such as trading, derivatives and investment banking. Typically, subsidiaries in emerging markets focus on granting loans and are characterized by low involvement in other types of activities.

In the case of parent banks, the estimates for the concentration ratio and liquid assets are not robust, indicating that these determinants are not crucial in mature markets for bank profitability. However, it should again be emphasized that the fixed effects (benchmark) estimates seem most trustworthy for three reasons. First, the presence of bank fixed effects allows omitted variable bias to be avoided through the omission of time-constant variables, which is not the case with the other approaches. Second, while individual effects are also present in the random effects approach, this approach requires an additional assumption regarding the independence of the distribution of individual bank effects and the value of regressors. If not fulfilled, this assumption results in inconsistency in the random effects estimator. Third, the number of parent banks is notable but not large, which raises doubts about the efficiency of the feasible GLS used in the random approach; thus, it may be concluded that the fixed effects (benchmark) approach should be treated as the most realistic one in the case of discrepancies.

While higher market concentration does not show a robust impact on parents, it still decreases subsidiaries' ROA. More concentrated banking sectors, such as those in host countries, do not enable increased profitability, which is not in line with our expectations. The lower competition in the market should place banks in a position to achieve stronger profitability figures. A probable reason for the above is the fact that foreign-owned banks are one group of market players, with domestic-owned and state-owned banks being others; therefore, they do not benefit as a group from increased market concentration. Moreover, foreign-owned banks may strive to increase their market share, and to achieve this, they offer lower margins for customers. Additionally, bank size does not show a robust impact in the case of subsidiaries. The size does not confirm statistical significance for parents, which suggests that the role of size is limited in mature markets. In general, parent banks are larger organizations in home markets that decided on foreign expansion. This ambiguous result 
suggests that these particular estimates should be interpreted with caution; thus, definite statements are not formulated in this case. The most likely reason for these differences is the presence of fixed time-constant effects in the baseline model. The persistence of the exploited time series in the baseline models is attributed to fixed bank effects, while in the other models, it results in the spurious significance of certain regressors as a consequence of omitted variable bias.

The NIM models (2.1.a for subsidiaries and 2.1.b for parents in Table 3) confirm previous findings regarding the role of the inflation rate, capital adequacy and cost-to-income ratio for subsidiaries and parents. The conclusions are also robust considering the role of the share of loans in total assets and the liquid asset ratio for subsidiaries. A high value for these variables relates to an increased NIM level. However, the cost of risk does not coincide with high NIM, which is not the case for ROA. These differences with the ROA model should be explained by the fact that credit margins (i.e. price of the credit) reflect not only the cost of funding but also a credit risk component for a given group of customers (e.g. retail or micro firms) or a customer (e.g. SMEs and corporations). The adequate pricing policy means setting a higher price when the credit risk is higher (e.g. Le and Ngo, 2020); therefore, one can observe a positive sign of the cost of risk, in contrast to the results of the benchmark model.

In the case of parent banks, size coincides with lower NIM, while for subsidiaries, the results are not robust. Larger parent banks represent more diversified business models, and thus, the importance of NIM as a profit driver is lower; however, they keep their pricing policy on the right track (positive signs of the coefficients for the cost of risk, except for its insignificance in the case of the fixed effects model). Moreover, higher market concentration decreases the margins, which is in line with expectations, regardless of the maturity of the market (developed vs. emerging); however, these indications are not robust.

The results of the ROE model (in Table 4) are - to a large degree - coherent with the ROA model. Except for the liquidity measures (deposit-to-loan and liquid assets ratios), the statistical significance of the results was confirmed. The most significant difference between the ROA and ROE models is the sign of the capital adequacy variable for subsidiaries, which should be explained by the fact that supervisory authorities in many emerging market countries, especially in Central Europe, represent a more restrictive approach than the global standard for capital regulations. Better capitalization of subsidiaries than parents is confirmed by descriptive statistics. In this way, higher capital adequacy reduces ROE through lower leverage.

In conclusion, the results discussed in this section support H1. Key bank-level variables that play a role for parent banks and subsidiaries are capital adequacy (as in Athanasoglou et al., 2008; Jara-Bertin et al., 2014; Djalilov and Piesse, 2016; Ohman and Yazdanfar, 2018), the cost-to-income ratio (as in Dietrich and Wanzenried, 2011; Tan, 2016) and the cost of risk (similar to Athanasoglou et al., 2008). In the case of liquidity, the conclusions are not as strong. Of the external variables, the rate of inflation (as in Athanasoglou et al., 2008; Chen and Liao, 2011; Jara-Bertin et al., 2014; Tan, 2016) is found to boost profitability.

\subsection{Subsample analysis}

To account for heterogeneity across countries, which might affect the analyzed relations, two division criteria are introduced. First, EU membership is taken into account to contrast EU and non-EU subsidiaries (most of the parent companies are headquartered in developed countries; thus, this type of division is not considered for the parent banks). Second, a dummy variable (VASSAL) is introduced, which accounts for whether home and host countries have strong historical links, i.e. host countries were politically and/or militarily influenced (conquered, vassalized or colonized) by home countries in the past. These links may indicate strong ties between home and host countries that may affect the policy to 
IJOEM 18,1

enter and operate in a given market. Emerging markets are attractive not only because they allow the generation of potentially higher returns but also because of historical sentiment. The division based on the VASSAL dummy is applied to both subsidiaries and parent banks. To preserve consistency, the tables are presented in Annex 4, while the discussion is presented below.

There are differences between EU and non-EU countries for all profitability measures (please see tables A.4.1, A.4.4 and A.4.7 in Annex 4). In comparison with models estimated for all subsidiaries, the role of most variables that are significant in the benchmark model has been confirmed; however, the biggest differences are observed for the ROE equation. For the ROA model, the key differences are related to the role of market competition (CR5), funding (deposit-to-loan ratio) and credit growth. The role of market concentration in decreasing profitability measured by ROA is more visible than in the case of other profitability measures, especially for EU subsidiaries. The significance of funding is not confirmed for ROA, but it is for EU subsidiaries in the NIM and ROE equations. Credit growth is found to improve the profitability (ROA, NIM and ROE) of EU subsidiaries, which may be treated as a sign of higher stability/predictability of business activities in EU countries. Moreover, the stock of liquid assets increases profitability in non-EU subsidiaries, underlying its positive role for profitability in less stable markets. In the EU markets, the situation may be regarded as stable in terms of market liquidity; therefore, the significance of this ratio is not confirmed. For NIM equations, there are more differences between EU and non-EU subsidiaries compared to the benchmark model. The results for non-EU subsidiaries are more similar to those for the whole sample, while EU subsidiaries show more differences. First, for EU subsidiaries, GDP growth and credit growth improve the interest margin, which is similar to the case of parent banks in ROA and ROE equations. Funding and size decrease NIM, which may indicate that subsidiary banks pay too much for deposits, e.g. to increase market share. Prevailing similarities in performance drivers between EU subsidiaries and parent banks may be treated as proof that markets of "new EU entrants" are close to becoming mature markets, while other emerging markets are still behind. These results provide support for H2.

From the perspective of historical links, comments are given first on similarities and differences between subsidiaries located in "vassal" and "non-vassal" countries (please see tables A.4.2, A.4.5 and A.4.8 in Annex 4) and then on the differences between subsidiaries and parent banks (please see tables A.4.3, A.4.6 and A.4.9 in Annex 4). Due to the large number of observations, the "non-vassal" models are chosen as the benchmark. In the case of both "vassal" and "non-vassal" subsidiaries, in all models, the results are consistent with the models for all banks, i.e. the inflation rate, the ratio of equity to total assets, the cost-to-income ratio and cost of risk (except for NIM), confirming their statistical significance and sign. Moreover, credit growth coincides with higher NIM in both groups. However, some differences exist between these groups regarding the role of other variables. More variables are statistically significant for "non-vassal" subsidiaries than for "vassal" subsidiaries. This is the case, for example, for GDP growth and the share of loans in total assets, which supports - as expected - higher profitability. Moreover, the growth of credit and liquidity increase ROA and ROE, while size diminishes NIM. This finding shows that foreign-owned banks from countries with no historical links with the parents' home countries react to a broader scope of stimuli and enjoy higher flexibility than those from countries with historical links. Against this background, in their profitability management, subsidiaries from "vassal" host countries are focused on key measures (capital adequacy, the cost-to-income ratio and the cost of risk supported by a higher inflation rate) that are strictly controlled by parent entities. These three bank-level variables, with minor exceptions, are significant for all parent banks, but again, in the case of parents with no previous historical links, more variables account for their profitability, but no pattern is observed. It can be concluded that parents and subsidiaries with no historical links are more 
flexible in their business activities to react to the current market situation when controlling for important bank-level ratios. These results support $\mathrm{H} 3$.

\section{Final remarks}

Previous studies on the performance of banks from emerging markets focused on differences in profitability between foreign-owned and domestic-owned banks or looked at their profitability from the perspective of the country's economic development. This paper analyzed whether subsidiaries and their parent banks represent differences in performance drivers. This perspective expands the stream of research focused on emerging markets and is most similar to the studies by Chen and Liao (2011) and Dietrich and Wanzenried (2014). The present analysis spanned the 1996-2015 period and covered a substantial portion of foreign-owned banks from emerging markets and their globally active parents.

Overall, differences in performance drivers exist between parents and subsidiaries (e.g. Dietrich and Wanzenried, 2014), but three bank-level characteristics, namely, the cost-toincome ratio, capital adequacy and the cost of risk, have a consistent role in various settings, which provides support for H1. These findings indicate a reasonable managerial focus on cost efficiency (e.g. Dietrich and Wanzenried, 2014) and bank safety, which is the focus of regulators and supervisors. Focus on cost management is regarded as a typical tool for improving performance, especially during crisis or restructuring periods. Capital adequacy has long been part of the regulators' agenda; however, after the global financial crisis, even more attention was given to deleveraging worldwide. Therefore, this factor appears to be relevant for banks' performance. The cost of risk demonstrates the change in the quality of assets, and regardless of the bank's business model, this determinant plays an important role in profitability, especially during economic downturns. Regarding macroeconomic variables, only inflation was found to be significant in various settings (e.g. Chen and Liao, 2011; Athanasoglou et al., 2008; Tan, 2016), confirming that inflationary expectations are taken into account in the banking business. In fact, this factor differs significantly between emerging markets and developed countries. Other macroeconomic features do not show such considerable gaps, and therefore, their role varies across settings. These variables for which "the apple does not fall far from the tree" play a crucial role in bank management. The remaining variables appear to allow more managerial flexibility and therefore less strict coordination between the parent and subsidiary. In this respect, "the apple may fall far from the tree" and flexibly adjust to the local conditions.

Moreover, subsidiaries operating in EU countries resemble their parents more than subsidiaries from other countries, which provides evidence of the greater maturity of the "new" EU markets in comparison with those in other emerging countries and demonstrates the strong integration within the EU, which gives support for H2. Not surprisingly, the subsidiaries from countries that were politically and/or militarily influenced (conquered, vassalized or colonized) by home countries in the past are more similar to their parents in terms of performance drivers than the subsidiaries from countries that were not influenced in this way, which supports H3.

In future studies, a broader set of subsidiaries in a cross-country setting should be analyzed; however, this approach is limited by data availability. Additionally, different groups of subsidiaries (not only EU vs. non-EU) should be taken into account. Historical as well as cultural issues require further cross-disciplinary research.

\section{References}

Ahamed, M. (2017), “Asset quality, non-interest income, and bank profitability: evidence from Indian banks”, Economic Modelling, Vol. 63, pp. 1-14. 
IJOEM

18,1

Albertazzi, U. and Gambacorta, L. (2009), "Bank profitability and the business cycle", Journal of Financial Stability, Vol. 5 No. 4, pp. 393-409.

Athanasoglou, P., Brissimis, S. and Delis, M. (2008), "Bank-specific, industry-specific and macroeconomic determinants of bank profitability", Journal of International Financial Markets, Institutions and Money, Vol. 18 No. 2, pp. 121-136.

Banyen, K. and Biekpe, N. (2020), "Financial integration and bank profitability in five regional economic communities in Africa", International Journal of Emerging Markets, ahead-of-print.

Beltratti, A. and Paladino, G. (2015), "Bank leverage and profitability: evidence from a sample of international banks", Review of Financial Economics, Vol. 27 No. 1, pp. 1058-3300.

Chen, S.H. and Liao, C.C. (2011), "Are foreign banks more profitable than domestic banks? Home- and host-country effects of banking market structure, governance, and supervision", Journal of Banking and Finance, Vol. 35 No. 4, pp. 819-839.

Claessens, S., Demirguc-Kunt, A. and Huizinga, H.P. (2001), "How does foreign entry affect domestic banking markets?”, Journal of Banking and Finance, Vol. 25 No. 5, pp. 891-911.

Claeys, S. and Vander Vennet, R. (2008), "Determinants of bank interest margins in Central and Eastern Europe: a comparison with the West”, Economic Systems, Vol. 32 No. 1, pp. 197-216.

Cull, R. and Martínez Pería, M. (2013), "Bank ownership and lending patterns during the 2008-2009 financial crisis: evidence from Latin America and Eastern Europe”, Journal of Banking and Finance, Vol. 37 No. 12, pp. 4861-4878.

Dahl, D., Shrieves, R.E. and Spivey, M.F. (2008), "Convergence in the activities of European banks", Journal of International Financial Markets, Institutions and Money, Vol. 18 No. 2, pp. 161-175.

Dietrich, A. and Wanzenried, G. (2011), "Determinants of bank profitability before and during the crisis: evidence from Switzerland", Journal of International Financial Markets, Institutions and Money, Vol. 21 No. 3, pp. 307-327.

Dietrich, A. and Wanzenried, G. (2014), "The determinants of commercial banking profitability in low-, middle-, and high-income countries", The Quarterly Review of Economics and Finance, Vol. 54 No. 3, pp. 337-354.

Djalilov, K. and Piesse, J. (2016), "Determinants of bank profitability in transition countries: what matters most?", Research in International Business and Finance, Vol. 38, pp. 69-82.

Du, B., Serrano, A. and Vianna, A. (2018), "Institutional development and foreign banks in Chile", International Review of Financial Analysis, Vol. 58 No. October 2017, pp. 166-178.

Havrylchyk, O. and Jurzyk, E. (2011a), "Inherited or earned? Performance of foreign banks in central and eastern Europe", Journal of Banking and Finance, Vol. 35 No. 5, pp. 1291-1302.

Havrylchyk, O. and Jurzyk, E. (2011b), "Profitability of foreign banks in central and eastern Europe", The Economics of Transition, Vol. 19 No. 3, pp. 443-472.

Houston, J. and James, C. (1998), "Do bank internal capital markets promote lending?", Journal of Banking and Finance, Vol. 22 Nos 6-8, pp. 899-918.

Houston, J., James, C. and Marcus, D. (1997), "Capital market frictions and the role of internal capital markets in banking", Journal of Financial Economics, Vol. 46 No. 2, pp. 135-164.

Jara-Bertin, M., Arias Moya, J. and Rodríguez Perales, A. (2014), "Determinants of bank performance: evidence for Latin America”, Academia. Revista Latinoamericana de Administración, Vol. 27 No. 2, pp. 164-182.

Jeanneau, S. and Micu, M. (2002), "Determinants of international bank lending to emerging market countries", Technical report, BIS Working Papers, Basel.

Kosmidou, K., Pasiouras, F. and Tsaklanganos, A. (2007), "Domestic and multinational determinants of foreign bank profits: the case of Greek banks operating abroad", Journal of Multinational Financial Management, Vol. 17 No. 1, pp. 1-15. 
Le, T.D. and Ngo, T. (2020), "The determinants of bank profitability: a cross-country analysis", Central Bank Review, Vol. 20 No. 2, pp. 65-73.

Lo, F.Y. and Tan, R. (2019), "Determinants of international subsidiaries' performances: a multi-level perspective of the subsidiary and parent company", International Journal of Emerging Markets, Vol. 15 No. 4, pp. 746-766.

Subsidiary banks in emerging markets

Madous, J. and de Guevara, J. (2004), "Factors explaining the interest margin in the banking sectors of the European Union", Journal of Banking and Finance,, Vol. 28 No. 9, pp. 2259-2281.

Öhman, P. and Yazdanfar, D. (2018), "Organizational-level profitability determinants in commercial banks: Swedish evidence”, Journal of Economic Studies, Vol. 45 No. 6, pp. 1175-1191.

Peek, J. and Rosengren, E. (1997), "The international transmission of financial shocks: the case of Japan”, The American Economic Review, Vol. 87 No. 4, pp. 495-505.

Peek, J. and Rosengren, E. (2000), "Collateral damage: effects of the Japanese bank crisis on real activity in the United States", The American Economic Review, Vol. 90 No. 1, pp. 30-45.

Saona, P. (2016), "Intra- and extra-bank determinants of Latin American Banks' profitability", International Review of Economics and Finance, Vol. 45, pp. 197-214.

Sturm, J. and Wiliams, B. (2008), "Characteristics determining the efficiency of foreign banks in Australia”, Journal of Banking and Finance, Vol. 32 No. 11, pp. 2346-2360.

Tan, Y. (2016), "The impacts of risk and competition on bank profitability in China”, Journal of International Financial Markets, Institutions and Money, Vol. 40, pp. 85-110.

To, H.M. and Tripe, D. (2002), "Factors influencing the performance of foreign-owned banks in New Zealand", Journal of International Financial Markets, Institutions and Money, Vol. 12 No. 3, pp. 341-357.

\section{Appendix}

The Appendix is available online for this article.

\section{About the authors}

Małgorzata Iwanicz-Drozdowska, $\mathrm{PhD}$, is a full professor of finance at the Institute of Finance at the Warsaw School of Economics. Her research fields include financial safety nets, financial stability and bank management. She is the author of more than 170 publications on the banking and financial services market and a participant of numerous research projects. Małgorzata Iwanicz-Drozdowska is the corresponding author and can be contacted at: miwani@sgh.waw.pl

Bartosz Witkowski, PhD, is a full professor at the Institute of Econometrics at the Warsaw School of Economics. His research specialization includes panel data analysis and its application in economics and finance. He co-operated as a lecturer or researcher with the Polish Academy of Science, National Bank of Poland, World Bank and Bank Guarantee Fund.

For instructions on how to order reprints of this article, please visit our website:

www.emeraldgrouppublishing.com/licensing/reprints.htm

Or contact us for further details: permissions@emeraldinsight.com 